\title{
Nuclear Medicine Technology Progress Report for Quarter Ending March 31, 1979
}

\author{
F. F. Knapp, Jr.
}

\section{OAK RIDGE NATIONAL LABORATORY} OPERATED BY UNION CARBIDE CORPORATION - FOR THE DEPARTMENT OF ENERGY 


\section{DISCLAIMER}

This report was prepared as an account of work sponsored by an agency of the United States Government. Neither the United States Government nor any agency Thereof, nor any of their employees, makes any warranty, express or implied, or assumes any legal liability or responsibility for the accuracy, completeness, or usefulness of any information, apparatus, product, or process disclosed, or represents that its use would not infringe privately owned rights. Reference herein to any specific commercial product, process, or service by trade name, trademark, manufacturer, or otherwise does not necessarily constitute or imply its endorsement, recommendation, or favoring by the United States Government or any agency thereof. The views and opinions of authors expressed herein do not necessarily state or reflect those of the United States Government or any agency thereof. 


\section{DISCLAIMER}

Portions of this document may be illegible in electronic image products. Images are produced from the best available original document. 
Printed in the United States of America. Available from National Technical Information Service

U.S. Department of Commerce

5285 Port Royal Road, Springfield, Virginia 22161

Price: Printed Copy $\$ 4.50 ;$ Microfiche $\$ 3.00$

This report was prepared as an account of work sponsored by an agency of the United States Government. Neither the United States Government nor any agency thereof, nor any of their employees, contractors, subcontractors, or their employees, makes any warranty, express or implied, nor assumes any legal liability or responsibility for any third party's use or the results of such use of any information, apparatus, product or process disclosed in this report, nor represents that its use by such third party would not infringe privately owned rights. 
Contract No. W-7405-eng-26

HEALTH AND SAFETY RESEARCH DIVISION

NUCLEAR MEDICINE TECHNOLOGY PROGRESS REPORT

FOR QUARTER ENDING MARCH 31,1979

F. F. Knapp, Jr.

MASTER

Work sponsored by

DOE Office of Health and

Environmentai Research

This repon NOTICE

sponsopon was prepared as an eccount of work Sponsored by the United States Govemment. Neither the United States nor the United States Department of Energy, nor any of their employees, nor any of their contractors, subcontractors, or their employees, makes any warranty, express or implied. or assimes any logal Thility or responsibility for the accuracy, completeness or usefulness of any information, apparatus, product or infringe privately owned rights.
int its use would not

Date Published - August 1979

NOTICE This document contains informotion of a proliminary nature. It is subject to revision or correction and therefore does not represent a final report.

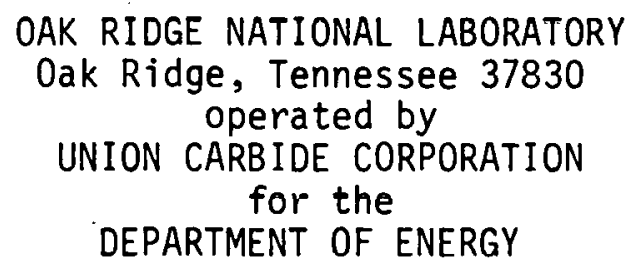


Previous reports in this series:

ORNL/TM-5809

ORNL/TM-5936

ORNL/TM-6044

ORNL/TM-6181

ORNL/TM-6371

ORNL/TM-6410

ORNL/TM-6638

ORNL/TM-6639

ORNL/TM-6771 
SUMMARY

In this report, we describe the preparation of a unique class of trimethyltin-substituted steroids that were designed because of the potential use of the ${ }^{117 m} \mathrm{Sn}$-labeled analogs for adrenal imaging. Several steroids were prepared that contained various structural modifications of both the nucleus and sidechain. The physical properties of these stable, crystalline products were consistent with the proposed structures. The trimethyltin-substituted steroids were readily prepared on the microscale in yields ranging from $40-80 \%$, which indicate that this methodology should be applicable for the preparation of the $117 \mathrm{~m} \mathrm{Sn}$-labeled steroids. Studies with the ${ }^{123 m}$ Te-labeled fatty acids have continued, and radiolabeled 6-telluraheptadecanoic acid and 11-telluraheptadecanoic acid have shown pronounced heart uptake in rats similar to that reported earlier for $123 m$ Te-labeled 9-telluraheptadecanoic acid. These combined results suggest that the position of the tellurium heteroatom has little effect on the heart uptake of the telluraheptadecanoic acids and that the pronounced heart uptake observed with $123 m$ Te-labeled 9-telluraheptadecanoic acid is therefore not simply a consequence of its isosteric similarity with oleic acid (9-octadecenoic acid).

As a result of our interest in the potential use of ${ }^{73} \mathrm{Se}-$ labeled agents for tomographic imaging applications, we have prepared several ${ }^{75} \mathrm{Se}-1$ abeled compounds for preliminary tissue distribution studies in rats. Significant heart uptake was observed with ${ }^{75}$ Se-1abeled-9selenoheptadecanoic acid, suggesting that the various structural features affecting heart uptake of seleno fatty acids should also be 
explored. In addition, ${ }^{75}$ Se-labeled 24-(isopropyl seleno)-chol-5-en3ß-01 was prepared and showed pronounced adrenal uptake in rats.

In this progress report, we also describe the results of continuing studies with ${ }^{11} \mathrm{C}-1$ abeled amino acids in a collaborative project with the Oak Ridge Associated Universities (ORAU). Recent patient studies at ORAU have established that ${ }^{11} \mathrm{C}-\mathrm{DL}$-tryptophan is superior to ${ }^{11} \mathrm{C}-\mathrm{DL}$-valine for pancreatic visualization by positron emission tomography. Nitrogen-13 $\left(T_{\frac{1}{2}}=10 \mathrm{~min}\right)$ was prepared for the first time in the ORNL 86-inch cyclotron and converted to ${ }^{13} \mathrm{~N}$-ammonia that was used successfully to visualize dog hearts.

\section{TIN-117m}

F. F. Knapp, Jr., T. A. Butzer, and K. R. Ambrose

In an earlfer report (ORNL/TM-6638), we described the properties of $117 m \mathrm{Sn}$ that make this radionuclide an attractive candidate for incorporation into various tissue-specific radiopharmaceuticals. More recently, we have described the preparation of $117 \mathrm{mSn}$-1abeled 12,12-dimethyl-12stannahexadecanoic acid as well as the results of tissue distribution studies in rats, with this potential myocardial imaging agent (ORNL/TM6639). Additional studies are now in progress to determine the effect of both the total chain length and the position of the dimethyltin moiety on the heart uptake of a series of $117 \mathrm{mSn}$-labeled fatty acids. We are also interested in the preparation of various other $117 \mathrm{~m} S \mathrm{n}-1$ abeled radiopharmaceuticals, and we have how explored the preparation of a novel series of steroids containing the trimethyltin moiety 
in the sidechain. While a variety of synthetic strategies were considered for the preparation of such compounds, we chose to investigate the reaction of trimethyltin-alkali metal salts with steroid substrates brominated in the sidechain, primarily because of the ready availability of the latter compounds that were used earlier to prepare the $123 m_{\text {Te-labeled adrenal }}$ imaging agents (ORNL/TM-6044). In addition, we had developed an efficient route for the preparation of the $\mathrm{Me}_{3} \mathrm{Sn}-\mathrm{Cl}$ (ORNL/TM-6638), which forms the crucial $\mathrm{Me}_{3} \mathrm{Sn}-\mathrm{Li}$ intermediate that readily reacts with halogenated substrates. We were therefore ready to attempt the preparation of nove? trimethyltin-substituted steroids. We found that commercial $\mathrm{Me}_{3} \mathrm{Sn}-\mathrm{Cl}$ formed the reactive $\mathrm{Me}_{3} \mathrm{Sn}-\mathrm{Li}$ intermediate by reaction with metallic lithium in either liquid ammonia or dry tetrahydrofuran. Addition of the brominated steroid substrates resulted in rapid, high-yield conversion to the trimethyltin-substituted steroids at room temperature. The structures of the steroids prepared in this manner are shown in Fig. 1 and include the following structural modifications: I, 24-(trimethyl

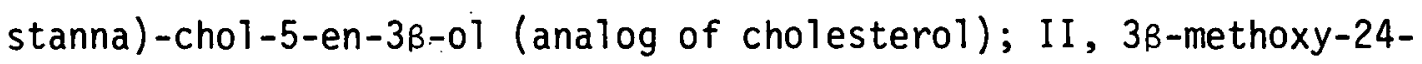
(trimethyl stanna)-chol-5-ene (hydrophobic $\mathrm{C}-3$ substituent); III, 23-

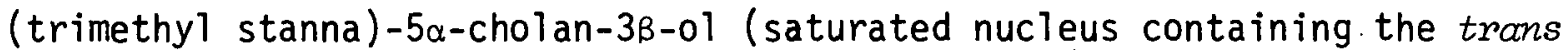

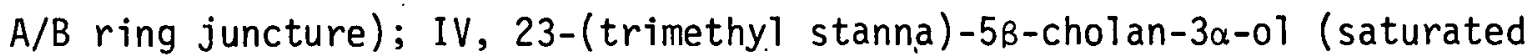
nucleus containing the cis $A / B$ ring juncture); and $V, 17 B-[$ (trimethy $]$

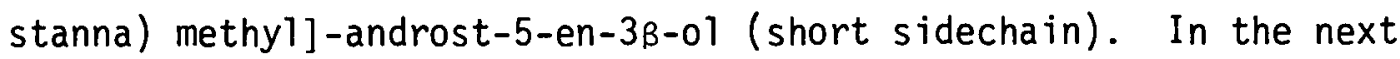
quarter, the $117 \mathrm{mSn}-1$ abeled steroids will be prepared, and tissue distribution experiments will be performed in rats in an attempt to define the important structural features required for the adrenal uptake of such compounds . 


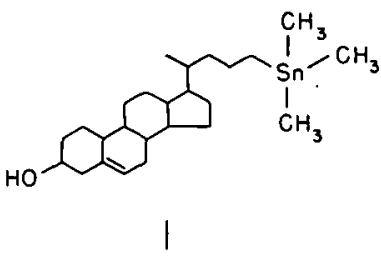<smiles>COc1ccc2c(c1)CCC2C(C)CC[Sn](C)(C)C</smiles>

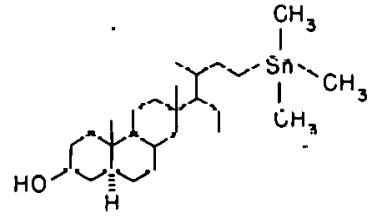

III

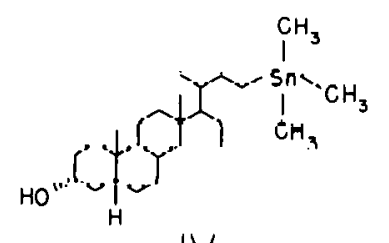

IV

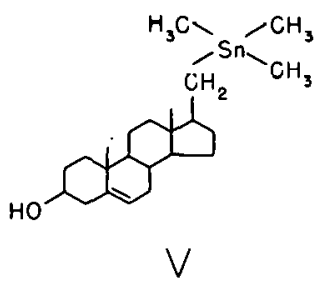

Fig. 1. The structure of steroids containing the trimethyltin

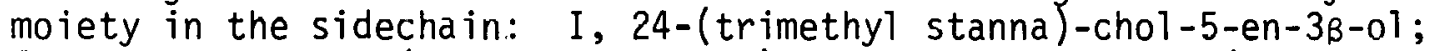
II, 3 $\beta$-methoxy-24-(trimethyl stanna)-cho 1-5-ene; III, 23-(trimethy

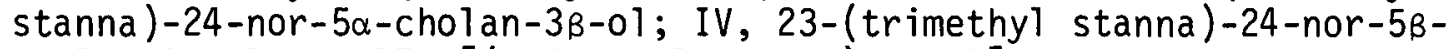

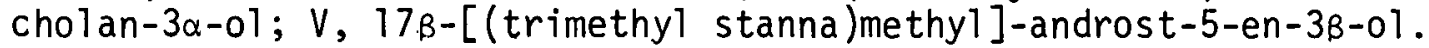


TELLURIUM- $123 m$

F. F. Knapp, Jr. and K. R. Ambrose

We have continued our studies with $123 m_{\mathrm{Te}}$-labeled-9-telluraheptadecanoic acid. An extensive tissue-distribution study in rats was completed for periods ranging from 2 minutes to 7 days after injection of the radiolabeled agent. The results (Fig. 2) indicate that the rapid heart uptake of radioactivity remains high for at least an hour after injection. The implications of these results are discussed in detail under the Selenium-75 section of this report (vide post).

In earlier studies (ORNL/TM-6638), we had investigated the effect of structure on heart uptake in rats of a variety of $123 \mathrm{mTe}$-labeled

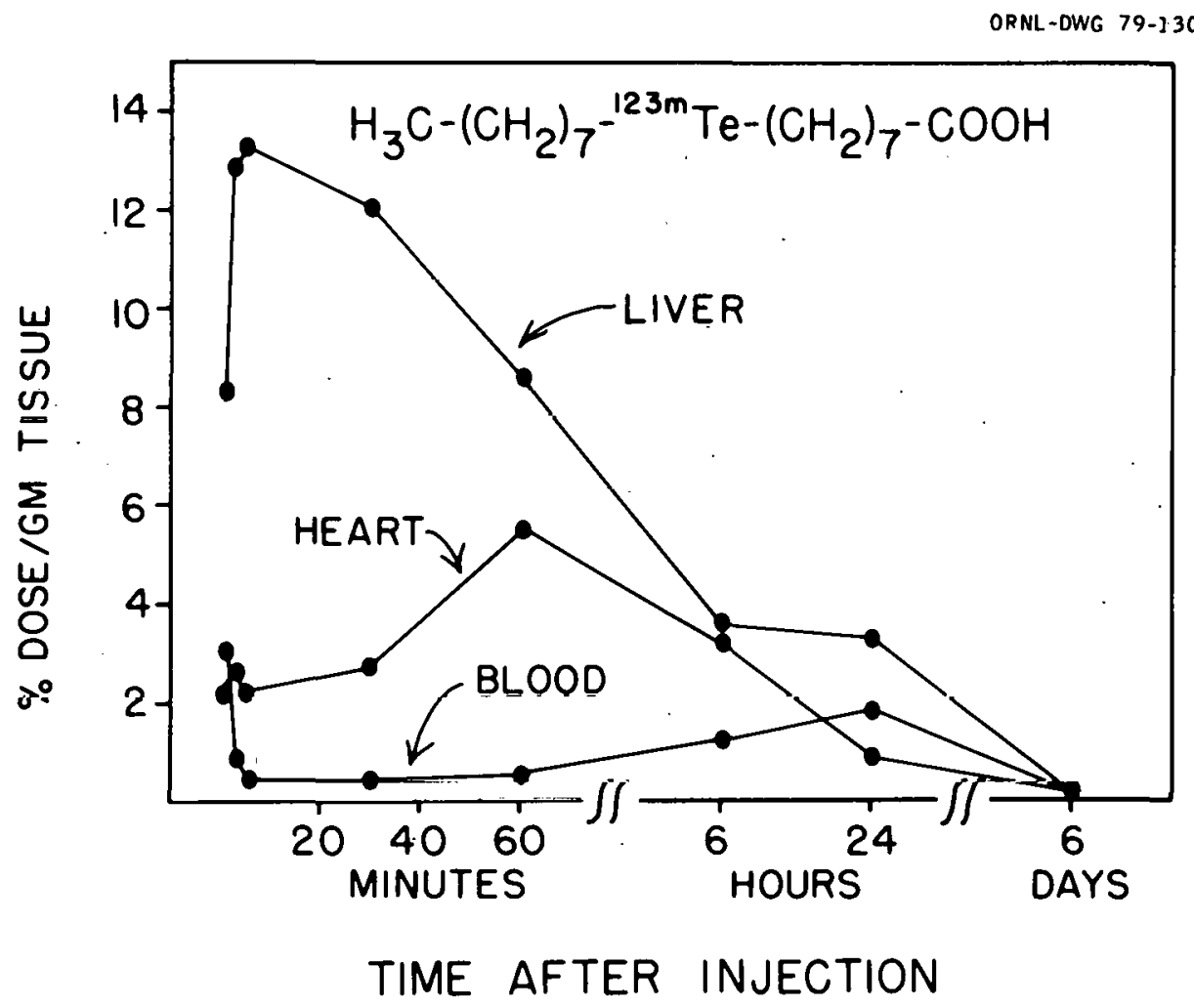

Fig. 2. Tissue distribution of radioactivity following intravenous administration of $123 \mathrm{mTe}-1$ abeled 9-telluraheptadecanoic acid to rats. 
telluro fatty acids. The structural variations included compounds in which both the total chain length and the position of the tellurium heteroatom were altered. The results of these studies indicated that while $123 m$ Te-labeled 9-telluraheptadecanoic acid showed significant heart uptake, the radiolabeled 6-telluraheptadecanoic acid did not. It was not clear from these results if the decreased heart uptake of the latter compound was a result of the shorter chain length or the altered position of the tellurium heteroatom. For these reasons, we have nuw studied the tissue distribution of the following three $123 m$ Te-labeled fatty acids: 9-telluratridecanoic acid (I), 11-telluraheptadecanoic acid (II) and 6-telluraheptadecanoic acid (III). Radiolabeled-(I) was prepared by basic hydrolys is of the methyl ester prepared by coupling of sodium butyl tellurol with methyl-8-bromooctanoate, and radiolabeled (II) was similarly generated following coupling of sodium hexyl tellurol with methy-10-bromooctanoate. For these two syntheses and all previously discussed preparations, the tellurols were generated by sodium buruhydride reduction of dialkyl ditellurides, which were prepared by alkyl halide alkylation of sodium ditelluride generated in liquid ammonia. Because of the insolubility of n-alkyl iodides larger than octyl iodide in this medium, an alternative method was required for the synthesis of diundecyl ditelluride used for the synthesis of (III). The diundecyl ditelluride was prepared by a simple method involving undecyl iodide alkylation of sodium ditelluride prepared by the reaction of sodium metal with tellurium in ethylene-diamine (R. A. Grigsby and K. J. Irgoìic, personal communication). The details of this method of preparation of sodium ditelluride will be described in a future report. Methyl-6-telluraheptadecanoate was 
prepared by coupling sodium undecyl tellurol with methyl-5-bromo-pentanoate and then converting to the free acid (III) by basic hydrolysis.

The results of tissue distribution studies with these three ${ }^{123 m T e-}$ labeled fatty acids are illustrated in Figs. 3-5. While 9-telluratridecanoic acid did not show pronounced heart uptake (Fig. 3), the 6-telluraand 11-tellura isomers of 9-telluraheptadecanoic acid showed significant heart uptake (Figs. 4 and 5 ). These studies indicate that total chain length is more important than the position of the tellurium heteroatom for heart uptake of $123 \mathrm{mTe}$-labeled fatty acids. Furthermore, the pronounced heart uptake originally observed with ${ }^{123 m}$ Te-labeled 9-telluraheptadecanoic acid must not simply result from the isosteric similarity between this compound and oleic acid as was originally suggested.

ORNL-DWG 79-13089

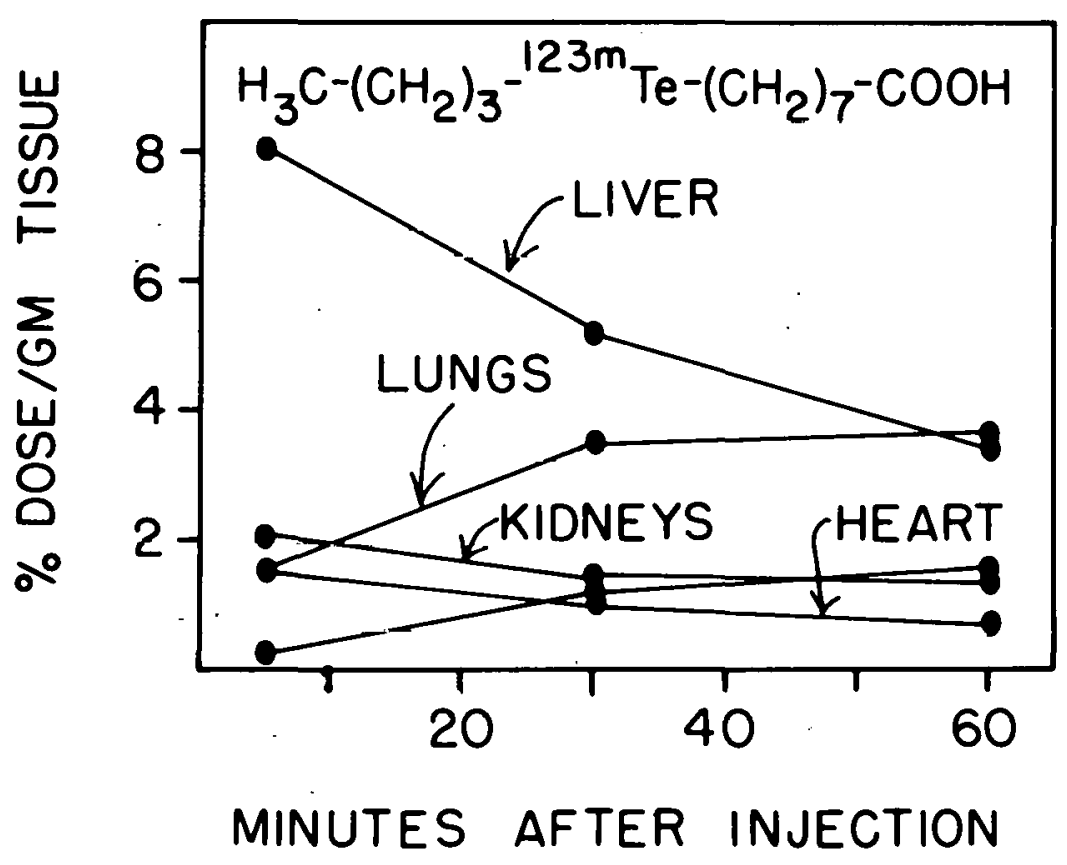

Fig. 3. Tissue distribution of radioactivity following intravenous administration of $123 \mathrm{mTe}$-labeled 9-telluratridecanoic acid to rats. 
ORNL-DWG 79-13085

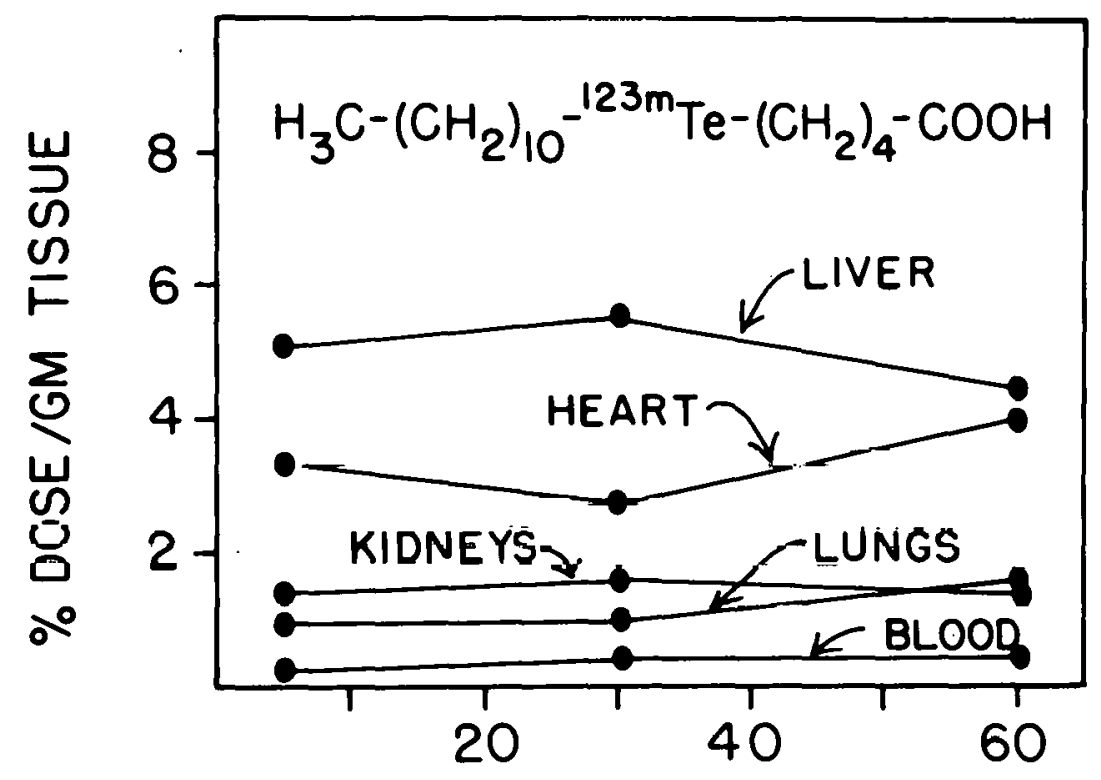

MINUTES AFTER INJECTION

Fig. 4. Tissue distribution of radioactivity following intravenous administration of $123 \mathrm{mTe}-1$ abeled 6 -telluraheptadecanoic acid to rats.

DRNL-DWG 79-.13086

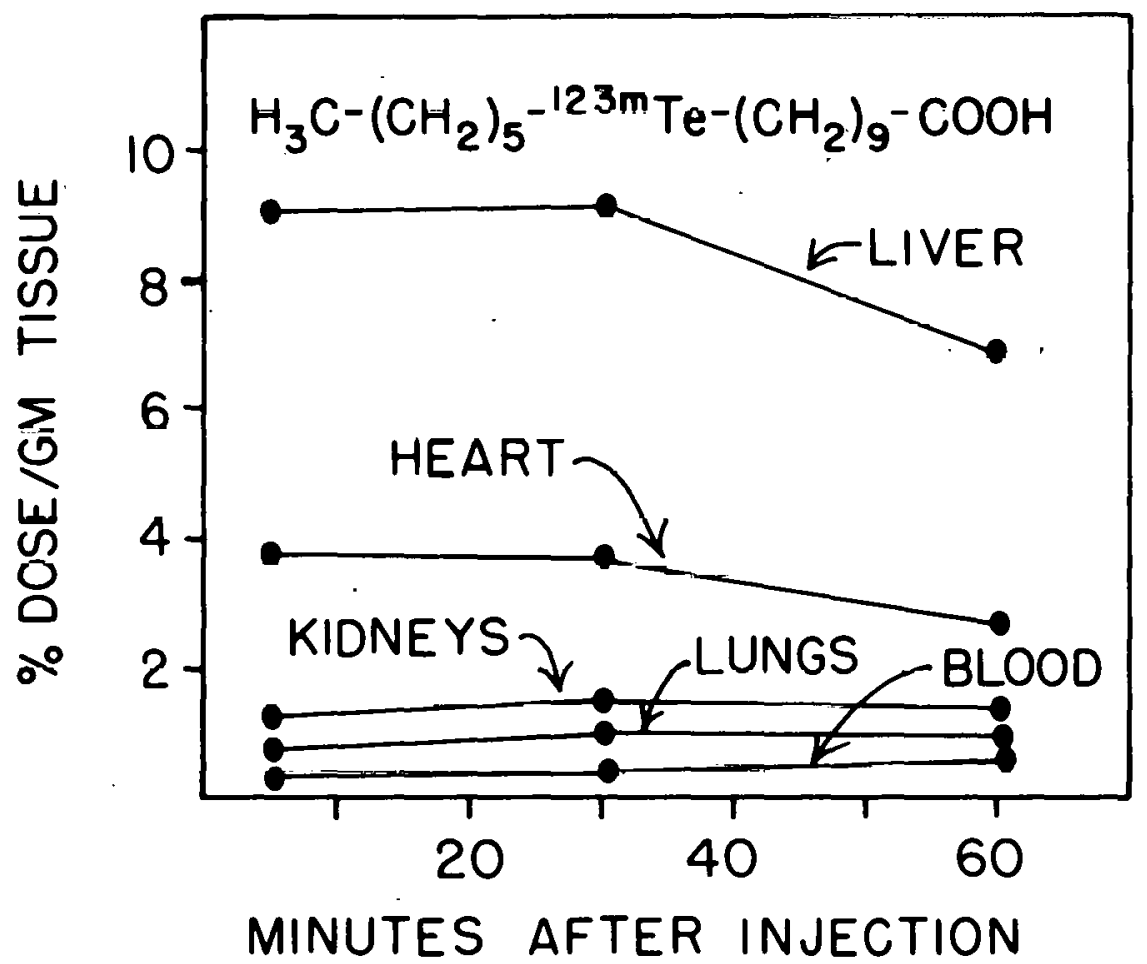

Fig. 5. Tissue distribution of radioactivity following intravenous administration of $123 \mathrm{mTe}$-labeled 11-telluraheptadecanoic acid to rats. 


\section{SELENIUM-75}

F. F. Knapp, Jr., T. A. Butler, and K. R. Ambrose

In ORNL/TM-6638, we described in detail the development of $123 \mathrm{mTe}$ labeled fatty acids as a unique class of potential myocardial-imaging agents. Tissue distribution studies with $123 m$ Te-labeled 9-telluraheptanoic acid demonstrated pronounced heart uptake of radioactivity following the intravenous administration of this agent in rats (vide ante). More recently, rat hearts have been clearly imaged following injection of $123 m$ Te-labeled 9-telluraheptadecanoic acid (ORNL/TM-6639). Because of the relative instability of the radiolabeled teliuro fatty acids, we have now initiated a series of experiments to investigate the effect of structure on heart uptake of ${ }^{75}$ Se-labeled fatty acids. Although the radionuclidic properties of ${ }^{75} \mathrm{Se}$ are not as attractive as those exhibited by $123 \mathrm{mTe}$, the anticipated greater stability of the seleno fatty acids coupled with the potential use of ${ }^{73}$ Se-labeled fatty acids for tomographic imaging of the myocardium has stimulated our interest in preparing and studying such compounds. Since extensive studies have been completed on $123 m$ Te-labeled 9-Lelluraheptadecanolc acid, we chose to prepare ${ }^{75}$ Se-labeled 9 -selenaheptadecanoic acid as the initial member of this potentially useful class of compounds. Methyl-9-selenahaptadecanoate $\left[\mathrm{H}_{3} \mathrm{C}-\left(\mathrm{CH}_{2}\right)_{7}-\mathrm{Se}-\left(\mathrm{CH}_{2}\right)_{7}-\mathrm{COOMe}\right]$ was prepared in high yield by coupling excess sodium octyl selenol with methyl-8-bromooctanoate in the usual manner. The methyl ester was fully characterized by the usual series of spectral measurements and was converted to 9-selenaheptadecanoic acid by ethanolic basic hydrolysis. While 9-tellurahepta- 
decanoic acid readily decomposes after formation, the 9-selenaheptadecanoic acid is much more stable and can be handled for several hours after generation. Detailed studies of the stability of seleno fatty acids are now in progress. The ${ }^{75} \mathrm{Se}-1$ abeled 9 -selenaheptadecanoic acid was prepared in the same manner by using ${ }^{75} \mathrm{Se}$-labeled diooctyl diselenide, which was generated by octyl iodide alkylation of the radiolabeled sodium diselenide. The results of tissue distribution studies in rats (Fig. 6) indicated significant heart uptake of radioactivity after intravenous administration of ${ }^{75} \mathrm{Se}-1$ abeled 9 -selenaheptadecanoic acid. The concentration of radioactivity in the heart tissue, however, was not as pronounced as that found following injection of $123 \mathrm{mTe}-9$-telluraheptadecanoic acid. This result was unexpected in light of the greater chemical sta-

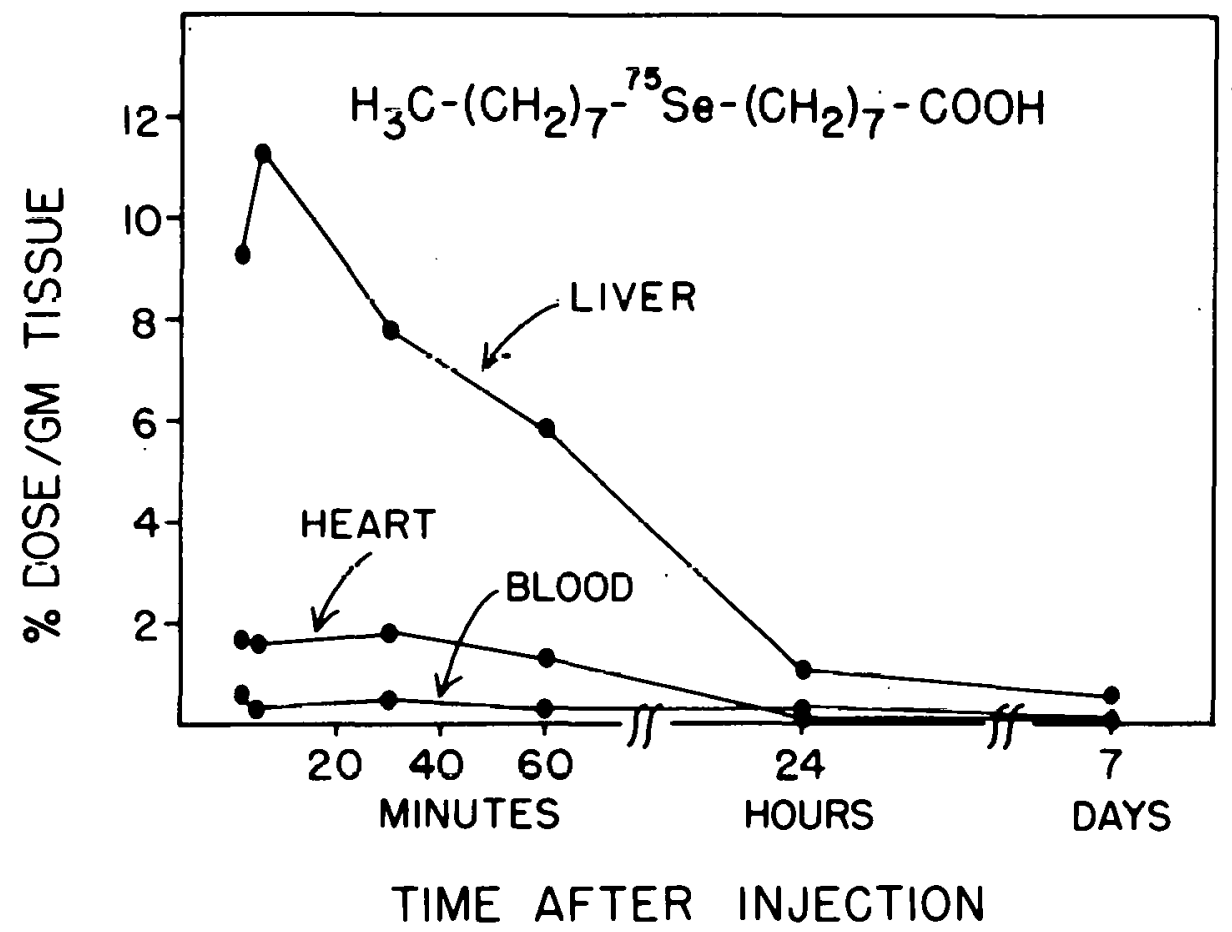

Fig. 6. Tissue distribution of radioactivity following intravenous administration of ${ }^{75} \mathrm{Se}-1$ abeled 9 -selenaheptadecanoic acid to rats. 
bility of the seleno fatty acid and may indicate that the telluro and seleno fatty acids are not metabolized similarly, as was originally expected. In addition, maximal heart uptake of the seleno fatty acids may be exhibited by an isomer of 9-selenaheptadecanoic acid. In the next quarter, a series of ${ }^{75} \mathrm{Se}-1$ abeled fatty acids will be prepared and tested in rats.

The results of tissue distribution studies with the radiolabeled 9-selena- and 9-telluraheptadecanoic acids have demonstrated that the significant levels of radioactivity in the heart remain relatively constant over at least the first hour after intravenous administration of these agents. In contrast, the initial pronounced heart uptake of alkanoic acids such as ${ }^{11} \mathrm{C}$-labeled palmitic acid and radioiodinated $\omega$-iodoheptadecanoic acid rapidly decreases as the radioactivity "washes out" of the heart tissue. The presence of the selenium or tellurium heteroatom appears to increase the residence time of such fatty acids in the heart tissue. This finding could be of considerable importance in the design of new radiolabeled fatty acids for myocardial imaging studies since one could envision the preparation of ${ }^{11} \mathrm{C}$-labeled or terminally radioiodinated fatty acids containing either stable selenium or tellurium in the fatty acid alkyl chain. The presence of the heteroatom would presumably increase the residence time of the radiolabeled fatty acids in the heart tissue resulting in longer counting periods during which greater diagnostic information could be obtained. During the next quarter, synthetic strategies will be developed for the preparation of such compounds. 
As a result of our continuing interest in the potential use of the $7.1 \mathrm{hr}$ half-life ${ }^{73} \mathrm{Se}$ positron emitter for tomographic imaging of the adrenal glands, we have prepared ${ }^{75}$ Se-24-(isopropyl seleno)-chol-5-en$3 \beta-01$ by the reaction of ${ }^{75}$ Se-1abeled isopropyl selenol with $3 \beta$-acetoxy24-bromo-chol-5-ene. Tissue distribution studies with this new agent in rats demonstrated significant adrenal uptake within $24 \mathrm{hr}$ after administration (Fig. 7).

ORNL-DWG 79-1,3087

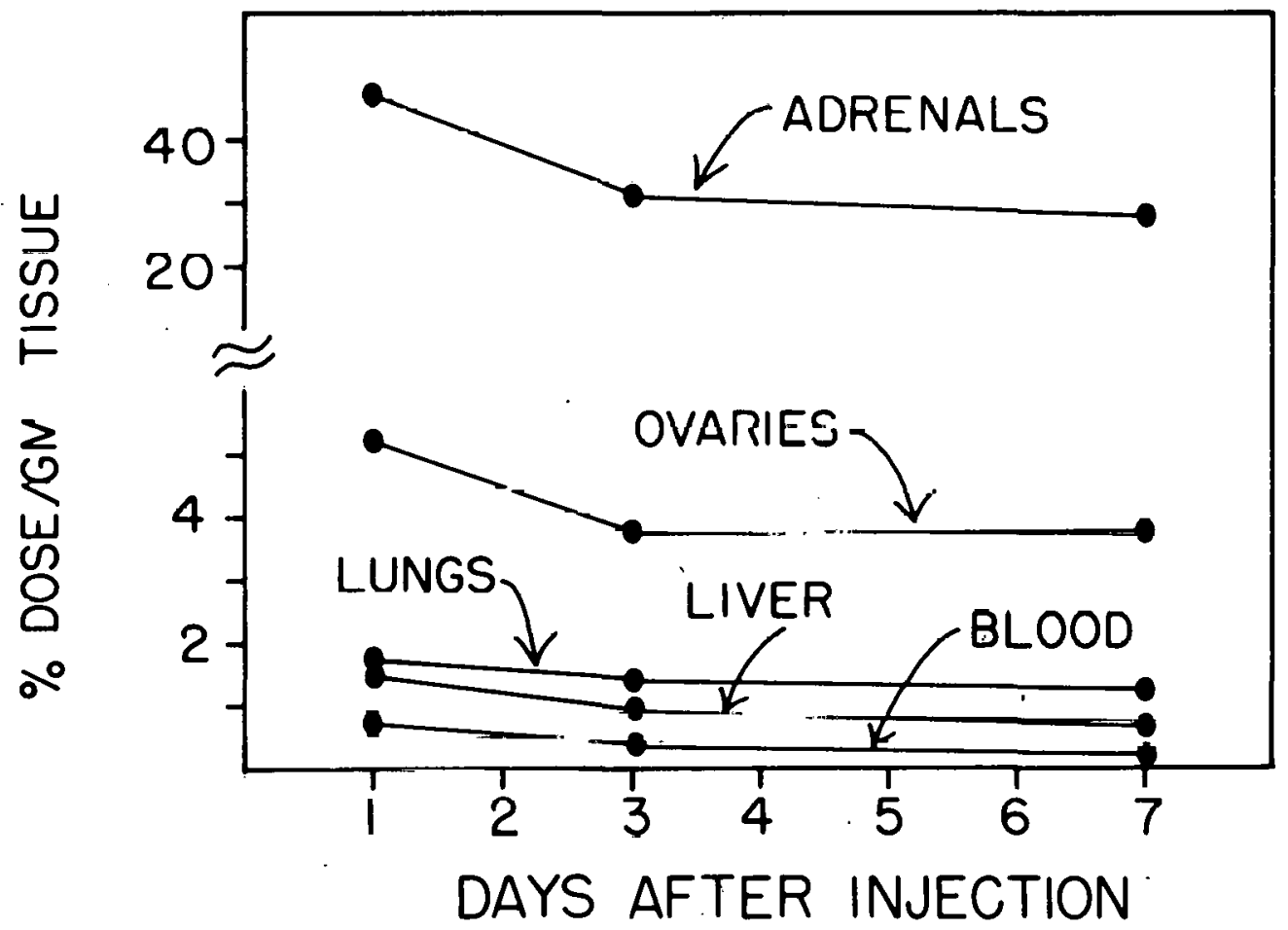

Fig. 7. The distribution of radioactivity in rat tissues following intravenous administration of ${ }^{75}$ Se-labeled 24 -(isopropyl seleno)-chol-5en $-3 \beta-01$. 


\author{
RADIONUCLIDES FOR MEDICAL COOPERATIVE PROGRAMS \\ F. F. Knapp, Jr., J. D. Hoeschele, and T. A. Butler \\ Carbon-11
}

Four ${ }^{11} \mathrm{C}$ production runs were made for the Medical Cooperative Program with Oak Ridge Associated Universities (ORAU) to study the application of ${ }^{11} \mathrm{C}-1$ abeled amino acids for tumor localization and pancreas imaging in human patients. Preparations of ${ }^{11} \mathrm{C}$-DL-valine, ${ }^{11} \mathrm{C}-\mathrm{DL}-$ tryptophan, and ${ }^{11} C-1$-aminocyclobutanecarboxylic acid ( $\left.{ }^{11} C-A C B C\right)$ were utilized in 12 human patient studies at ORAU using positron emission tomography for organ visualization. The results of these studies definitely indicated that ${ }^{11} \mathrm{C}-\mathrm{DL}$-tryptophan was superior to ${ }^{11} \mathrm{C}-\mathrm{DL}$-valine as a pancreatic imaging agent in these human subjects. Carbon-11-labeled carbon monoxide was also prepared during this quarter for preclinical inhalation studies in dogs at ORAU.

\title{
Nitrogen-13
}

As part of our continuing Medical Cooperative Program with ORAU to study the application of short-lived positron emitting radionuclides in nuclear medicine, ${ }^{13} \mathrm{~N}\left(T_{\frac{1}{2}}=10 \mathrm{~min}\right)$ was prepared for the first time in the ORNL 86 -inch cyclotron by the $160(p, \alpha)^{13} \mathrm{~N}$ nuclear reaction and converted to ${ }^{13} \mathrm{NH}_{3}$, which is an attractive candidate for tomographic heart imaging applications. Two cyclotron runs resulted in $45 \mathrm{mCi}$ and $90 \mathrm{mCi}$ products, which were used by ORAU to scan successfully the hearts of two dogs. 
Platinum-195m

Three shipments of $195 \mathrm{mPt}-1$ abeled $\mathrm{Na}_{2} \mathrm{PtCl}_{6}$ were made to the University of Kentucky Medical Center as part of the continuing Medical Cooperative Program to study platinum antitumor compounds. Three shipments of $195 \mathrm{mPt}-1$ abeled cis- $\left[\mathrm{Pt}\left(\mathrm{NH}_{3}\right)_{2} \mathrm{Cl} \mathrm{C}_{2}\right]$ (cis-DDP) were made to the University of Southern California. A Medical Cooperative was also established with Dr. S. J. Lippard from the Chemistry Department of Columbia University to investigate the relative nucleosome binding of $195 \mathrm{mPt}$-labeled cis- and trans-DDP. Dr. Lippard performed these studies at the Medical Research Council Laboratory of Molecular Biology at Cambridge, England, where he was supplied with two shipments of $195 \mathrm{mpt}$ labeled cis-DDP and one shipment of the radiolabeled trans-isomer.

\section{OTHER NUCLEAR MEDICINE TECHNOLOGY GROUP ACTIVITIES}

J. D. Hoeschele and F. F. Knapp, Jr. attended the Secourid Inter= national Symposium on Radiopharmaceuticals at Seattle, Washington, on March 19-22.

Visitors for this period included Dr. K. J. Irgolic from the Chemistry Department at Texas A \& M University who presented a seminar on March 28 describing the biological formation of various organic compounds of arsenic. A research and development subcontract has been initiated with Dr. Irgolic to investigate the chemical synthesis of organic compounds of tellurium and tin that are of biological interest. On Apri1 16 and 17, R. A. Grigsby, a graduate student with Dr. Irgolic, visited to consult on various aspects of these studies. On March.13, 
Dr. A. Oberman, director of the Division of Preventive Medicine at the University of Alabama in Birmingham, was briefed on the research activities of the Nuclear Medicine Technology Program in an effort to explore the possibility of establishing cooperative projects between the two institutions. On March 8, a group of physicians, nurses, and technicians attending an ORAU course entitled Medical Planning and Care in Radiation Accidents visited the facilities.

Potassium-43 was supplied to several institutions on a cost-recovery basis. Five shipments of ${ }^{43} \mathrm{~K}$ were made to the University of Mississippi Medical Center for coronary disease studies in human patients. In addition, four shipments were made to the V. A. Center at Wood, Wisconsin, for investigations of the potassium uptake in the hearts of stressed rats. Two shipments were made to the Shields Warren Radiation Laboratory of the Harvard Medical School at the Children's Hospital Medical Complex at Boston, Massachusetts, for microdosimetric studies. Single shipments were also made to the National Institute for Environmental Health Sciences at Research Triangle Park, North Carolina, and the University of Connecticut Health Center. 
PAPERS AND PUBLICATIONS

Papers

J. D. Hoeschele, T. A. Butler, and J. A. Roberts, "Microscale Synthes is and Biodistribution Studies of Pt-195m-Labeled Cis-Dichlorodiammineplatinum (II), cis-DDP," 2nd International Symposium on Radiopharmaceuticals, Seattle, Washington, Marçh 19-22, 1979.

F. F. Knapp, Jr., K. R. Ainibruse, A. P. Callahall, R. A. Griysby, and K. J. Irgolic, "Te-123m-Labeled Isosteres of Palmitoleic and 0leic Acids Show High Myocardial Uptake," 2nd International Symposium on Radiopharmaceuticals, Seattle, Washington, March 19-22, 1970.

D. V. Woo, F. F. Knapp, Jr., A. P. Callahan, and T. A. Butler, "An Efficient Microscale Preparation of Sn-117m-Tin TetrachlorideA Pivotal Intermediate for the Synthes is of $\mathrm{Sn-117m-Labeled}$ Radiopharmaceuticals," 2nd International symposium on Radiopharmaceuticals, Seattle, Washington, March 19-22, 1979.

Publications

J. D. Hoeschele, T. A. Butler, and J. A. Roberts, "Microscale Synthesis and Biodistribution Studies of Pt-195m-Labeled Cis-Dichlorodiammineplatinum(II), Cis-DDP," Am. J. Roentgenol., 132, 488, 1979 (Abstract).

F. F. Knapp, Jr., "Telluroamino Acids-The Synthesis of Telluromethionine," J. Org. Chem., 44, 1007, 1979. 
F. F. Knapp, Jr., "The Modified Hunsdiecker Degradation of Bile Acids and Related Compounds," Steroids, 33, 245, 1979.

F. F. Knapp, Jr., K. R. Ambrose, A. P. Callahan, R. A. Grigsby, and K. J. Irgolic, "Tellurium-123m-Labeled Isosteres of 0leic and Palmitoleic Acids Show High Myocardial Uptake," Am. J: Roentgenol., 132, 487, 1979 (Abstract).

D. V. Woo, F. F. Knapp, Jr., A. P. Callahan, and T. A. Butler, "An Efficient Microscale Preparation of Sn-117m-Tin Tetrachloride -A Pivotal Intermediate for the Synthesis of Sn-117m-Labeled Radiopharmaceuticals," Am. J. Roentgenol., 132, 487, 1979 (Abstract).

\section{Reports}

F. F. Knapp, Jr., Nuclear Medicine Progress Report for Quarter Ending December 30,1978 , ORNL/TM-6771. 
THIS PAGE

WAS INTENTIONALLY

LEFT BLANK 
ORNL/TM-6916

INTERNAL DISTRIBUTION

1. K. R. Ambrose

2. S. I. Auerbach

3. J. A. Auxier

4. J. M. Becker (Consultant)

5. T. A. Butter

6. A. P. Callahan

7. J. A. Cox

8. J. M. Dougherty

9. L. A. Ferren

10. R. B. Gammage

11. A. S. Garrett, Jr.

12. W. R. Garrett

13. C. E. Guyer

14. J. D. Hoeschele

15. S. V. Kaye

16-20. F. F. Knapp, Jr.

21. E. Lamb

22. B. F. Maskewitz

23. C. H. Nowl in
24. C. L. Ottinger

25. D. C. Parzyck

26. H. Postma

27. M. E. Ramsey

28. C. R. Richmond

29. J. A. Roberts

30. A. F. Rupp (Consultant)

31. C. D. Scott

32. W. D. Shults

33. M. R. Skidmore

34. J. B. Storer

35. P. J. Walsh

36. H. A. Wright

37-38. Central Research Library

39. Document Reference Section

40-41. Laboratory Records Department

42. Laboratory Records, ORNL RC

43. ORNL Patent Section

EXTERNAL DISTRIBUTION

44. S. J. Adelstein, M.D., Shields Warren Radiation Lab., Boston, MA 02115

45. H. L. Atkins, M.D., BNL, Upton, NY 11973

46. A. B. Brill, M.D., Vanderbilt Univ. Hospital, Nashville, TN

47. T. F. Budinger, M.D., Donner Lab., LBL, Berkeley, CA 94720

48. M. A. Davis, Radiology Dept., Harvard Medical School, Boston, MA 02115

49. P. A. DeSimone, M.D., V.A. Hospital, Lexington, KY 40507

50. P. Harper, M.D., Frankl in McLean Memorial Research Institute, Chicago, IL 60637

51. R. L. Hayes, ORAU, Oak Ridge, TN 37830

52. J. Hollifield, M.D., Vanderbilt Univ. Hospital, Nashville, TN

53. K. J. Irgolic, Chemistry Dept., Texas A\&M Univ., College Station, TN 77840

54. D. E. Kuh1, M.D., UCLA, Lab. of Nuclear Medicine, Los Angeles, CA 90024

55. J. S. Laughl in, Sloan-Kettering Inst. for Cancer Research, New York, NY 10021

56. A. Lengendre, M.D., UT-School of Veterinary Medicine, Knoxville, TN 37920

57. C. C. Lushbaugh, ORAU, Oak Ridge, TN 37830

58. J. N. Maddox, DOE-OHER, Washington, DC 20545 
59. Office of Assistant Manager, Energy Research and Development, DOE-ORO, Oak Ridge, TN 37830

60. H. A. O'Brien, LASL, Los Alamos, NM 87545

61. J. K. Poggenburg, Medical Products Division, UCC, Tuxedo, NY 10987

62. P. Richards, BNL, Upton, NY 11973

63. A. Solomon, M.D., UT MRCH, Knoxville, TN 37920

64-90. Technical Information Center, DOE, Oak Ridge, TN 37830

91. J. Venditti, National Cancer Institute, Silver Springs, MD 20910

92. H. E. Walburg, CARL, Oak Ridge, TN 37830

93. W. H. Weyzen, M.D., DOE-OHER, Washington, DC 20545

94. A. P. Wolf, BNL, Upton, NY 11973

95. W. Wolf, University of Southern Calffornia, Los Angeles, CA 90033

96. R. W. Wood, Jr., OHER, Washington, DC 20545 